\title{
The global financial crisis: origin, contagion and impacts on Ethiopia
}

\author{
Issac Paul ${ }^{1}$
}

\begin{abstract}
The financial crisis that erupted in September 2008-following more than two years of financial turmoil has become global crisis for the world economy. An attempt is made in this study to assess the possible causes of the origin, contagion and impact of the current global financial crisis with particular emphasis on Africa and Ethiopia. It also provides a summarized historical overview of past global financial crises in view of the economic theories of financial crises. The study utilizes the fundamental economic theories related to financial crisis to depict and illustrate the bigger picture. The paramount importance of this study is a detailed analysis of the current global financial crisis, and its wide ranging impacts by creating a clear link with past financial crises in different regions of the world. The method followed throughout this paper is qualitative and descriptive in nature. The transmission channels for the Ethiopian economy in the study are the knock on effects, external sector and commodity prices, investment, official transfers and remittance and the impact on the flower industry.
\end{abstract}

Keywords: Global Financial Crisis, recession, Investment, Ethiopia.

\section{Background}

The financial crisis that erupted in September 2008-following more than two years of financial turmoil-has become global crisis for the world economy. Economic activity in high-income and developing countries alike fell abruptly in the final quarter of 2008. The fallout is unemployment on the rise, and poverty set to increase in developing economies, bringing with it a substantial deterioration in conditions for the worlds poor and most vulnerable. The outbreak of the financial crisis provoked broad liquidation of investments, substantial loss in wealth worldwide, a tightening of lending conditions, and a widespread increase in uncertainty. Higher borrowing costs and tighter credit conditions, coupled with the increase in uncertainty provoked a global flight on quality, caused firms to cut back on investment expenditures, and households to delay purchases of big-ticket items. This rapid increase in precautionary saving led to a sharp decline in global

${ }^{1}$ Associate Professor, Institute of Regional and Local Development Studies, College of Development Studies, Addis Ababa University, Ethiopia (E-mail:

issacpaul562000@yahoo.com) 
investment, production, trade, and gross domestic product (GDP). The sharpest declines in economic activity were concentrated among countries specialized in the production of durable and investment goods and in countries with serious existing macroeconomic vulnerabilities. The drop in economic activity, combined with much weaker capital flows to developing countries, is placing a large number of low- and middle-income countries under serious financial strain. Greater integration of the global economy and the increasing importance of private actors in international finance over the past three decades have brought enormous benefits to developing countries, but they also have widened the scope for economic turmoil. What began as a bursting of the U.S. housing market bubble and a rise in foreclosures has ballooned into a global financial crisis. Some of the largest and most venerable banks, investment houses, and insurance companies have either declared bankruptcy or have had to be rescued financially. In October 2008, credit flows froze, lender confidence dropped, and one after another the economies of countries around the world dipped toward recession. The crisis exposed fundamental weaknesses in financial systems worldwide, and despite coordinated easing of monetary policy by governments and trillions of dollars in intervention by governments and the International Monetary Fund (IMF), the crisis continues in different regions of the world.

\section{Statement of the Problem}

The current global financial crisis has shaken the world economy by causing a global turmoil. The crisis, which started as a housing bubble in the U.S got rapidly transmitted to Europe forcing different financial institutions (including banks, insurance companies, and security investors) and giant multinational companies to bankruptcy. Due to foreclosures people became homeless and were laid off from their jobs due to the crisis. Many financial institutions in the west have gone into total bankruptcy with valueless paper based assets. Many have rescheduled their investment plans, canceled ongoing projects and laid off huge number of work force. Least developed countries of the world, including those in Africa, are also being affected by the decline in the demand of their exports and a decrease in private and public transfers. The impact of the crisis on the Ethiopian economy has remained controversial with contradicting comments from different experts and state officials. Hence, this paper will try to address this gap by undertaking a detailed analysis of the impact of the crisis on the Ethiopian economy. 


\section{Objectives of the study}

The objectives of the study are:-

1. To assess the possible causes of the origin, contagion and impact of the current global financial crisis with particular emphasis on Africa and Ethiopia.

2. To provide a summarized historical overview of past global financial crises in relation to the economic theories of financial crises.

3. To analyze the economic theories related to financial crisis to depict and illustrate the bigger picture.

4. To suggest policy adjustments which need to be implemented to avoid further worsening of the economic condition of the country.

\section{Scope of the study}

The study begins with a brief historical description of financial crises from the Great Depression of 1930s, followed by the Latin American debt crisis of 1980s, and the Asian financial crisis of 1997/98. It systematically analyses the causes, transmission mechanisms and wide ranging impacts of the current global financial crisis in developed and developing countries especially in African and more so in Ethiopian context.

\section{Methodology}

The study has relied completely on secondary data sources. The sources of data are mainly from different international financial institutions like International Monetary Fund, World Bank, African Development Bank, and also Ethiopian government institutions like National Bank of Ethiopia, Investment Bureau, Ethiopian Customs Authority, and Ministry of Finance and Economic Development (MoFED). The method followed throughout this paper is qualitative and descriptive in nature. The period of the study starts from September 2008 after which the current global financial crisis has erupted. The transmission channels of the financial crisis for the Ethiopian economy in the study are the knock on effects, 
external sector and commodity prices, investment, official transfers and remittance and the impact on the flower industry.

\section{Organization of the study}

The organization of the study is as follows: this section is introductory in nature and provides the problem, objectives, significance, and scope of the study. The next section provides a background of the global financial crisis by bringing up historical records, describing economic theories on financial crisis and summarizing the impact of past financial crises. The third section focuses fully on the current global financial crisis by drawing facts on the origin, contagion and effects of the crisis with specific emphasis on Ethiopian economy. The last section indicates policy adjustments that need to be implemented to avoid further worsening of the economic condition of the country.

\section{Review of related literature}

\section{Historical background}

A salient feature in the history of the global economic activities has been the alternative occurrence of prosperity and depression. The period of prosperity is manifested in terms of increment in productive capacity, business alternatives, entrepreneurship, innovation, and profit, while the panic of a failing economy could start from any one of the sectors, like housing or banking, and finally result in an economy wide concern. However, as indicated in the scope of the study, the discussions will be based on financial crises which have left remarkable effects on the global economy: the Great Depression of 1930s, the Latin American debt crisis of 1980s, the Asian financial crisis of 1997/98 and the current global economic crisis (2008/09).

\section{The Great Depression}

The Great Depression is one of the catastrophic economic downturns witnessed in recent history with a wide reaching effect in North America, Europe, and other industrialized nations of the world with a duration of ten years (1929-1939). The depression started with a collapse of stock market of 
the New York Stock Exchange in 1929. The decline of the stock exchange was followed by a precipitous decline in asset value decreasing the credit portfolio of banks. Surprisingly, 11,000 of the 25,000 banks in USA have stumbled to bankruptcy by 1933. Related to this, a decrease in consumer spending and demand, and hence productivity has aggravated the downward spiral of the global economy. Even though the crisis did start in United States of America, it did not take long for it to be transmitted to Europe and other industrialized nations as there was an intimate affiliation forged between USA and those economies as a result of World War I (Bordo, 2000).The downturn was so severe that it resulted in a $50 \%$ decrease in industrial output in USA, a 33\% lay-off rate in Germany, and a $25 \%$ decline in exports of Great Britain. Further East, the Depression was extended to the Japanese manufacturing output, which was significantly affected. What has made the impacts of the depression prolonged were the improper protective policy measures taken by individual countries including imposing tariffs, and setting quotas on foreign imports (Kindleberger, 1986).

\section{The Latin American debt crisis}

The Latin American debt crisis that happened in 1980s was the result of Latin American countries failure to repay the international debts. Fundamentally, the period was an era of economic opening up for Latin American countries notably Brazil, Argentina, and Mexico investing hugely on infrastructure and heavy industries. Latin American Countries were having a debt of US \$ 315 billion in 1983 with a cumulative annual growth rate of $20.4 \%$, approximately $50 \%$ of the region's GDP, while debt service was around US $\$ 66$ billion. The increase in interest rate in USA and Europe as a buffer from increased oil price has made it hard for indebted Latin American Countries to pay their debts back. This crisis has caused a massive capital outflow from these countries decreasing the real GDP growth rate of the region by $2.3 \%$ and per capita income by around $9 \%$.

\section{Asian financial crisis}

The Asian financial crisis was one of the giant crises of recent history that gripped much of Asia beginning in 1997 with widespread offsite panic. The center of crisis was Southeast Asia, where Indonesia, South Korea, and Thailand constituting the worst hit nations, while Hong Kong, Malaysia, Laos, Philippines, People's Republic of China, Taiwan, Singapore, Brunei, 
and Vietnam taking their fair share of the hustle. The crisis has been attributed to distorted incentives within lender-borrower relationship of Asian economies. This has availed a large quantity of credit in a highlyleveraged economic climate pushing up the asset price to unsustainable level. As the artificially swelled asset price start to collapse, individuals and companies started to default on their creditors. The disequilibrium in the lender-borrower relationship has caused a panic to lenders urging them to withdraw deposits from the countries causing credit crunch and further bankruptcies. A further capital flight has also put in place a depreciative pressure on the exchange rates of these economies forcing them to increase domestic currency rate, and buy up any excess domestic currency at a fixed exchange rate with foreign reserves to safeguard their currency value. Yet any of the policy responses could not result in significant change in the tide of fleeing capital, growing foreign-currency-denominated-liabilities, and deepening crisis.

The historical lessons learnt from these regional crises are outflow of capital, exchange rate instability, credit crunch and bankruptcies. Similar experiences are seen in the present global financial crisis which erupted in September 2008.

\section{Economic theories of financial crises}

In most of the historic crises, two or more of the above mentioned causative factors were operating parallel making it challenging to model crises. Hence, it remains a difficult task to have a representative model. Of the economic models explaining financial crises, Minsky's (1996) theory is the popular one which proposes an explanation to financial crises in a closed economy which argues that financial fragility is a typical feature of capitalist economy where firms choose among hedge finance, speculative finance, and ponzi finance. For hedge finance, income flows are expected to meet financial obligations in every period, including both the principal and the interest on loans. For speculative finance, a firm must roll over debt because income flows are expected to only cover interest costs. None of the principal is paid off. For ponzi finance, expected income flows will not even cover interest cost, so the firm must borrow more or sell off assets simply to service its debt. The hope is that either the market value of assets or income will rise enough to pay off interest and principal. According to Minsky (ibid) 
financial fragility go along with business cycle embracing a coupling of hedge finance with recessionary firm, speculative finance with expansionary firm and ponzi finance with illusionary firm. According to the theory, ponzi financing is the most fragile type of financing structure, which might grow to economy wide crisis through contagion.

Figure1: Relationship between Business Cycle and Financing

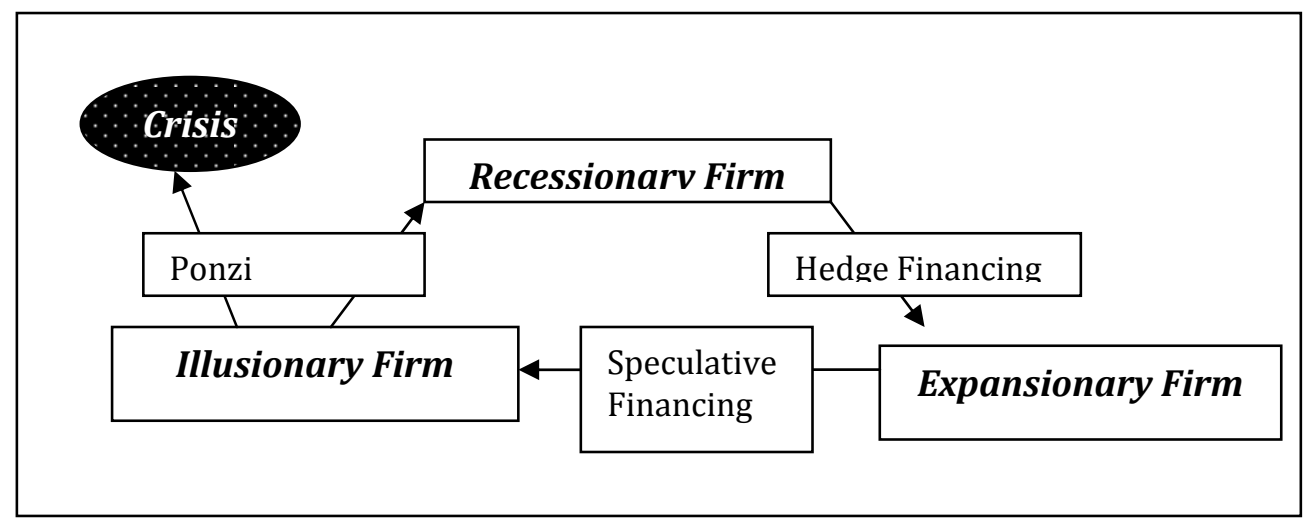

The business cycle of firms is an oscillatory phasing where they swing from recessionary trend to expansionary trend and to illusionary trend. Provided that the cycle is managed in such a way that it would not result in bankruptcy, it is healthy to go through the three steps. A firm that is in recessionary stage will get additional financing only as hedge finance. As the productivity of the firm gets well, then it could be possible to get speculative financing by predicting about profits. Nevertheless, the increase in speculative finance that a firm gets obliged to could make its liability grow bigger than its asset base. At this stage of ponzi financing, the way to get loan from banks will be only through convincing the banks that it is still a viable firm that do have a hope to withstand financial tides. Provided that this situation of a firm in ponzi financing gets worse, it would be inevitable for the firm to stumble to bankruptcy.

Other less widely adopted models of financial crises are the Coordination Theory and the Herd Behavior Theory. In the coordination theory, the fundamental economic factor behind most economic crises is supposed to be consumer feedback. As far as the feedback of consumers stays positive towards different financial market indicators, it would be safe for investors to 
invest. On the other hand a decline in positivism of consumer feedback will alert investors to withhold investment leading to potential crisis (Krugman, 1979). The other model, the herd behavior model, fostered by economists like Banerjee (1992) assumes crises as results of the mimicking nature of financial investors in decision making, which would overvalue asset prices in an artificial way. Provided that the adaptive learning of investors would make them decide according to what others do, a slight decline in asset price could lead to a total collapse.

\section{Emergence and impacts of the current global financial crisis on Africa and Ethiopia}

\section{Origin and contagion of global financial crisis}

Each financial crisis is unique, yet each bears some resemblance to others. In general, crises have been generated by factors such as an over shooting of markets, excessive leveraging of debt, credit booms, miscalculation of risks, rapid out flow of capital from a country, mismatches between asset types, unsustainable macroeconomic policies, off-balance sheet operations by banks, lack of experience with new financial instruments, and deregulation without sufficient market monitoring and oversight (CRS, 2008). The current global financial crisis started to show its effects in the middle of 2007/08 fiscal year. It started in the U.S. and European investment banks, insurance firms and mortgage banks as a result of their failure to apply stringent risk controls for bad debts, collateralize debt insurance and overlooking potential frauds. As shown in Figure 2 the current crisis harkens back to the 1997-98 Asian financial crisis in which Thailand, Indonesia, and South Korea had to borrow from IMF to service their short-term foreign debt and to cope with a dramatic drop in the values of their currency and deteriorating financial condition. Determined not to be caught with insufficient foreign exchange reserves, countries subsequently began to accumulate dollars, Euros, pounds, and yen in record amounts. This was facilitated by the U.S. trade (current account) deficit.

By mid-2008, world currency reserves by governments had reached $\$ 4.4$ trillion with China's reserves alone approaching \$ 2 trillion, Japan's nearly \$ 1 trillion, Russia’s more than $\$ 500$ billion, and India, South Korea, and 
Brazil each with more than $\$ 200$ billion. The accumulation of hard currency assets was so great in some countries that they diverted some of their reserves into sovereign wealth funds that were to invest in higher yielding assets than the U.S. Treasury and other government securities.

Following the Asian financial crisis, much of the world's "hot money" began to flow into high technology stocks. The so-called "dot-com boom" ended in the spring of 2000 as the value of equities in many high-technology companies collapsed. After the dot-com bust, more "hot investment capital" began to flow into housing markets - not only in the United States but in other countries of the world. At the same time, China and other countries invested much of their accumulations of foreign exchange into U.S. Treasury and other securities. While this helped to keep U.S. interest rates low, it also tended to keep mortgage interest rates at lower and attractive levels for prospective home buyers.

This housing boom coincided with greater popularity of the securitization of assets, particularly mortgage debt (including sub prime mortgages), into collateralized debt obligations (CDOs). A problem was that the mortgage originators often were mortgage finance companies whose main purpose was to write mortgages using funds provided by banks and other financial institutions or borrowed. They were paid for each mortgage originated but had no responsibility for loans gone bad. Of course, the incentive for them was to maximize the number of loans concluded. This coincided with political pressures to enable more Americans to buy homes, although it appears that Fannie Mae and Freddie $\mathrm{Mac}^{2}$ were not directly complicit in the loosening of lending standards and the rise of sub prime mortgages. In order to cover the risk of defaults on mortgages, particularly sub prime mortgages, the holders of CDOs purchased credit default swaps ${ }^{3}$ (CDSs). These are

\footnotetext{
2 Fannie Mae (Federal National Mortgage Association) is a government-sponsored enterprise (GSE) chartered by Congress in 1968 as a private shareholder-owned company with a mission to provide liquidity and stability to the U.S. housing and mortgage markets. It operates in the U.S. secondary mortgage market and funds its mortgage investments primarily by issuing debt securities in the domestic and international capital markets. Freddie Mac (Federal Home Loan Mortgage Corp) is a stockholder-owned GSE chartered by Congress in 1970 as a competitor to Fannie Mae. It also operates in the secondary mortgage market. It purchases, guarantees, and securitizes mortgages to form mortgage-backed securities. For an analysis of Fannie Mae and Freddie Mac's role in the subprime crisis, see David Goldstein and Kevin G. Hall, "Private sector loans, not Fannie or Freddie, triggered crisis,” McClatchy Newspapers, October 12, 2008.

3 A credit default swap is a credit derivative contract in which one party (protection buyer) pays a periodic fee to another party (protection seller) in return for compensation for default (or similar credit event) by a reference entity. The reference entity is not a party to the credit default swap. It is not necessary for the protection buyer to suffer an actual loss to be eligible for compensation if a credit event occurs. The protection buyer gives up the risk of default by the reference entity, and takes on the risk of simultaneous default by both the protection seller and the reference credit. The protection seller takes on the default risk of the reference entity, similar to the risk of a direct loan to the
} 
types of insurance contract (a financial derivative) that lenders purchase against the possibility of credit event (a default on a debt obligation, bankruptcy, restructuring, or credit rating downgrade) associated with debt, a borrowing institution, or other referenced entity. The purchaser of the CDS does not have to have a financial interest in the referenced entity, so CDSs quickly became more of a speculative asset than an insurance policy. As long as the credit events (defaults) never occurred, insurers of CDSs could earn huge amounts in fees relative to their capital base (since these were technically not insurance, they did not fall under insurance regulations requiring sufficient capital to pay claims, although credit derivatives requiring collateral became more and more common in recent years). The sellers of the CDSs that protected against defaults often covered their risk by turning around and buying CDSs that paid in case of default.

As the risk of defaults rose, the cost of the CDS protection rose. Investors, therefore, could arbitrage between the lower and higher risk CDSs and generate large income streams with what was perceived to be minimal risk. In 2007, the notional value (face value of underlying assets) of credit default swaps had reached \$ 62 trillion, more than the combined gross domestic product of the entire world (\$ 54 trillion), although the actual amount at risk was only a fraction of that amount. By July 2008, the notional value of CDSs had declined to \$ 54.6 trillion and by October 2008 to an estimated \$ 46.95 trillion. The system of CDSs generated large profits for the companies involved until the default rate, particularly on sub prime mortgages, and the number of bankruptcies began to rise. Soon the leverage that generated outsized profits began to generate outsized losses, and in October 2008, the exposures became too great for companies such as AIG.

reference entity. See CRS Report RS22932, Credit Default Swaps: Frequently Asked Questions, by Edward V. Murphy. 
Figure 2: Origins of the financial crisis: the rise \& fall of risky mortgage \& other debt

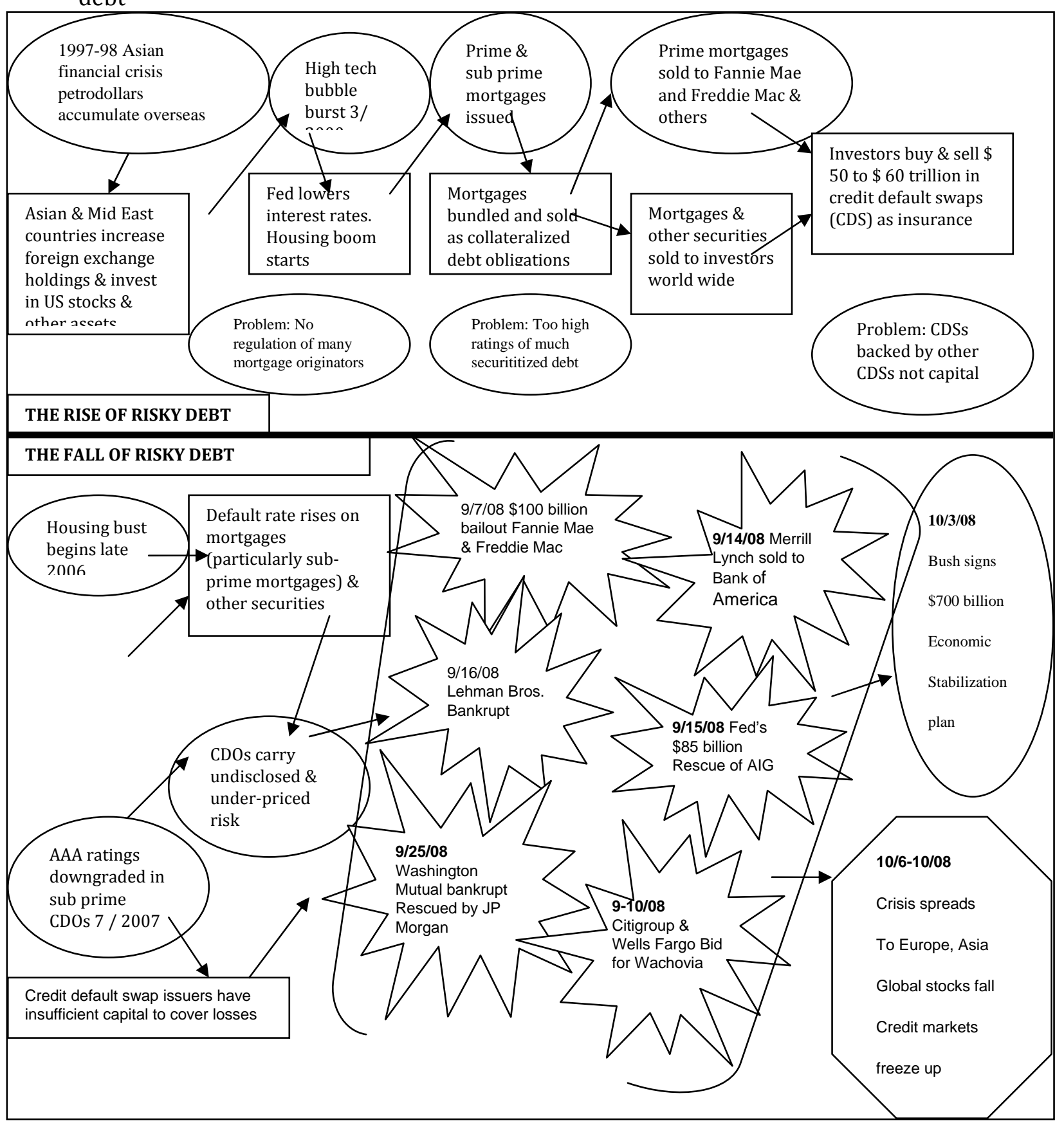

Source: CRS, 2008 
Generally, the current global financial meltdown demonstrates the increasing inter-connectedness of the world by affecting the livelihoods of almost everyone. This crisis also brought an important point that U.S. is still the center of the financial world. As indicated in CRS (2008), U.S. is the major guarantor of the international financial system, the provider of dollar, which is a widely used currency reserve and international medium of exchange, and a contributor to much of the financial capital that sloshes around the world, any shake off in the U.S. financial system would take a global hue.

\section{Impacts of the crisis on African countries}

A preliminary estimate of the impact of the global economic crisis in Africa is very minimal as compared to other regions. The African Development Bank Report (2009) attributes this to Africa's low share of total capital flows, the limited number of countries leveraging funds on international markets and the limited correlation between Africa and industrialized countries' financial markets. However, the global crisis is gradually showing its effects on the fragile economy of the African continent. These countries, especially the Sub-Sahara African countries, are to a large extent dependent on the economies of the developed countries with regard to aid and other forms of development assistance

The African Development Bank has outlined four major risks for African Countries that are faced with the financial crisis and the global recession. These risks are the capital out flow risk, fiscal risk, export risk and the liquidity risk. With regard to the capital outflow risk, as a result of the decline in the private capital flows and investment, the resulting impact will prevail on the exchange rate and the ability to finance the current account deficit. A decline in revenue as a result of low demand for products coupled with the increase in expenditure will exacerbate the fiscal risk in these countries. The slow demand for primary products will leave the export of these countries unprotected while the weakening of the global financial market plays its own role in affecting the banking sector and the government. The fiscal balance and current account balance as percentage of the total GDP is shown in the following table. 
Table 1: Overall fiscal balance and current account balance (\% GDP), 2007-2009

\begin{tabular}{|l|l|l|l|l|l|l|l|}
\hline \multirow{2}{*}{ No. } & & \multicolumn{3}{|c|}{ Fiscal Balance } & \multicolumn{3}{c|}{ Current Account } \\
\cline { 3 - 8 } & & $\mathbf{2 0 0 7}$ & $\mathbf{2 0 0 8}$ & $\mathbf{2 0 0 9}$ & $\mathbf{2 0 0 7}$ & $\mathbf{2 0 0 8}$ & $\mathbf{2 0 0 9}$ \\
\hline $\mathbf{1}$ & Africa & $\mathbf{1 . 8 9}$ & $\mathbf{1 . 8 2}$ & $\mathbf{- 5 . 0 6}$ & $\mathbf{2 . 6 6}$ & $\mathbf{2 . 7 2}$ & $\mathbf{- 4 . 0 5}$ \\
\hline 1.1 & $\begin{array}{l}\text { North Africa } \\
\text { (including Sudan) }\end{array}$ & 2.90 & 2.38 & -5.79 & 10.65 & 10.14 & 1.75 \\
\hline 1.2 & $\begin{array}{l}\text { Sub-Saharan } \\
\text { Africa }\end{array}$ & 1.25 & 1.48 & -4.61 & -2.37 & -1.68 & -7.70 \\
\hline $\mathbf{2}$ & By Region & & & & & & \\
\hline 2.1 & Central Africa & 5.46 & 10.7 & 3.26 & -1.47 & 3.88 & -9.39 \\
\hline 2.2 & Northern Africa & 3.51 & 2.98 & -6.15 & 13.05 & 12.15 & 3.02 \\
\hline 2.3 & Southern Africa & 2.47 & 2.32 & -3.46 & -3.34 & -3.01 & -7.65 \\
\hline 2.4 & Western Africa & -0.54 & -0.08 & -9.00 & 0.11 & 0.72 & -8.57 \\
\hline
\end{tabular}

Source: African Development Bank, February 2009

Demand for the primary products, which most of the African countries are exporting is gradually slowing down. For example, mining companies in the Democratic Republic of Congo are forced to scale back, postpone or abandon their investment plan due to the decline in the demand for these products.

\section{Impact of global economic slowdown on Ethiopian economy}

We have seen how the current global economic crisis has affected many European and African countries. In the Ethiopian case, the impact would not be significant on the financial sector since it is not completely integrated with the global financial system. In Ethiopia's financial sector, mortgage borrowing is not a particularly significant activity of the national economy, is not directly affected by any "Sub-Prime Mortgage" crisis. However, it would be naïve to say that Ethiopia's economy will not be affected by the credit crunch or global recession, not least because a big chunk of the money spent 
in Ethiopia comes from those countries that are now in despair. The money flowing into the country; be it through international aid or remittance etc, is all subject to this global phenomenon. The effects of the crisis were being felt by the Ethiopian economy from October 2008 onwards; therefore the analysis is based on the years 2007/2008 and 2009 .

\section{Knock on effects of the global credit crunch}

The country's 2008-2009 budget shows that about 33\% will be availed from bilateral aid, direct budget assistance and loans. Out of the approved 4.5 billion dollars budget, 1.5 billion dollar is expected to be covered by loan, aid and direct budget subsidies. Hence, no doubt that global recession will have a knock-on effect on Ethiopia's economy. For donor countries to honor their pledges would be unrealistic when they are faced with domestic economic instabilities. The particular projects related to ambitious "Millennium Development Goals", such as eradicating extreme poverty and hunger; achieving universal primarily education; promoting gender equality and empowering woman; reducing child mortality; improving mental health; combating HIV and AIDS, malaria and other diseases; ensuring environmental sustainability and developing a global partnership for development will not be honored fully. Western countries will try to impose many restrictions so that they can withhold their money for their own use. The short term effects of the above measures of donors will result in the declining reserve of foreign currency with the National Bank.

\section{Impact on external sector performance and commodity prices}

Ethiopia's economy is heavily dependent on export of primary commodities. The predominant dependence on agricultural activities has caused the country's vulnerability to price shocks around the world. The major commodities that the country exports are coffee, oilseeds, leather products, pulses, meat products, chat and flower. During the first quarter of 2008/09, the balance of payments registered a deficit of USD 142.2 million, which was slightly less than the USD 155.6 million deficits registered in the preceding quarter. External sector performance of quarter II (2008/09) shows that export receipts reached USD 270.9 million, 1.2 percent higher than that of last year same quarter. Quarter II of 2008/09 is feeling the greatest hit of the crisis. When compared with quarter I of the same fiscal year, there is a 22.8 percent decline in total exports. Together with the decline in exports, the country's trade balance is showing negative figures in quarter II (1766.9) 
which means that there is a significant trade deficit. (National Bank of Ethiopia, 2009)

Table 2 Value of major export items

\begin{tabular}{|c|c|c|c|c|c|c|c|c|}
\hline \multirow{3}{*}{ Particulars } & \multirow{2}{*}{\multicolumn{2}{|c|}{$\begin{array}{c}\begin{array}{c}2007 / 08 \\
\text { (In Millions of } \\
\text { USD) }\end{array} \\
\text { Qtr II }\end{array}$}} & \multicolumn{4}{|c|}{$\begin{array}{c}2008 / 09 \\
\text { (In Millions of USD }\end{array}$} & \multirow{2}{*}{\multicolumn{2}{|c|}{$\begin{array}{l}\text { Percentage } \\
\text { Change }\end{array}$}} \\
\hline & & & \multicolumn{2}{|c|}{ Qtr I } & \multicolumn{2}{|c|}{ Qtr II } & & \\
\hline & A & $\begin{array}{c}\% \\
\text { share }\end{array}$ & B & $\begin{array}{c}\% \\
\text { share }\end{array}$ & C & $\begin{array}{c}\% \\
\text { share }\end{array}$ & C/B & C/A \\
\hline Coffee & 52.6 & 19.6 & 133.3 & 37.9 & 41.7 & 15.4 & -68.7 & -20.6 \\
\hline Oilseeds & 31.4 & 11.7 & 45.1 & 12.8 & 51.7 & 19.1 & 14.7 & 64.4 \\
\hline $\begin{array}{l}\text { Leather and Leather } \\
\text { products }\end{array}$ & 29.1 & 10.9 & 25.3 & 7.2 & 28.5 & 10.5 & 12.6 & -2.1 \\
\hline Pulses & 31.1 & 11.6 & 21.5 & 6.1 & 22.5 & 8.3 & 4.7 & -27.7 \\
\hline $\begin{array}{l}\text { Meat \& Meat } \\
\text { Products }\end{array}$ & 5.6 & 2.1 & 8.5 & 2.4 & 7.1 & 2.6 & -16.7 & 27.5 \\
\hline Fruits \& Vegetables & 2.9 & 1.1 & 4.7 & 1.3 & 2.9 & 1.1 & -37.8 & 2.7 \\
\hline Live Animals & 16.1 & 6.0 & 15.7 & 4.5 & 16.8 & 6.2 & 7.2 & 4.5 \\
\hline Chat & 28.8 & 10.7 & 32.9 & 9.4 & 34.4 & 12.7 & 4.4 & 19.6 \\
\hline Gold & 15.9 & 5.9 & 17.5 & 5.0 & 20.3 & 7.5 & 16.0 & 27.9 \\
\hline Flower & 24.0 & 9.0 & 26.8 & 7.6 & 28.8 & 10.6 & 7.6 & 20.3 \\
\hline Others & 30.4 & 11.4 & 20.3 & 5.8 & 16.2 & 6.0 & -20.4 & -46.8 \\
\hline Total & 267.7 & 100.0 & 351.7 & 100.0 & 270.9 & 100.0 & -23.0 & 1.2 \\
\hline
\end{tabular}

Source: Ethiopian Revenues and Customs Authority, 2008

The effect of the crisis is still seen on the Ethiopian imports, where there is a 10.3percent decline in quarter II from quarter I of the same fiscal year. This does not mean that the decline in imports is harming the economy, but the cause of the decline is shortage of foreign currency reserve in the national bank, again caused by the global economic slow down. There is a significant decline in the value of export of coffee (being the major export commodity of the country). In Quarter I of 2008-09, coffee registered an export value of USD 133.3 million while it declined to USD 41.7 million in Quarter II of the same fiscal year (68.7 \% decline).. It is a well known fact that the decline in coffee exports shakes the whole economy since $20-25$ percent of the total exports of the country are dependent on this crop. Total revenue derived from the export sector has declined from USD 351.7 million in Quarter I to USD 270.9 million in quarter II. The above ups and downs are clear indications of the evil effects of the global economic crisis (Ethiopian Revenue and Customs Authority, 2008). 


\section{Effect of the crisis on the country's flower industry}

If we compare the growth rates between quarter II of 2007-08 and 2008-09, there is a significant decline in exports of flowers (20.3 percent to 7.6 percent). If we compare Quarter I and II of 2008/2009 with regards to flower export, there is very little increase in its value as shown in Table 1

\section{Official transfers and remittance}

The other source of Ethiopian foreign exchange is remittance from Ethiopians living abroad. The remittance from Ethiopians living abroad reached $\$ 1$ billion in 2007-08. Recession and loss of jobs in the West could affect Ethiopians in Diaspora and reduce the money flowing into the country. For instance, individual transfers have declined from USD 503,455 million in quarter one to USD 485,297 million, registering a 3.6 percent decline. It is not possible to accurately predict the impact of global recession on Diaspora remittance, but even 30\% reduction in remittance would mean a \$300 million loss to the economy, which is equivalent to the lose of foreign exchange income from coffee export.

The aid that Ethiopia receives is predominantly dependent on funds coming from countries and multi-national companies which are heavily affected by the current economic downturn. The official transfers have increased from USD 281,256 million to USD 513,228 million in the 2008/2009 first and second quarters. This is due to the fact that the IMF gave budgetary assistance to all developing countries to withstand the current financial crisis. On the "Net Transfers" there is a 32.2 percent increase in transfers, mainly resulting from assistance given by the IMF (National Bank of Ethiopia 2009).

\section{Investment}

As expected, the global crisis has affected Ethiopia's investment environment. In March 2008, the number of projects that were approved was 2100, while only 1966 were approved in December of the same year. The size of the capital investment was 61333.2 million USD in June 2008 while it declined to only 28,510.3 million in December 2008. With regards to the potential employment creation of both permanent and temporary workers, the same decline was registered, running from 672489 workers in June 2008 to 240960 in December 2008 (National bank of Ethiopia, 2009). 
Table 3 Investment Indicators

\begin{tabular}{|l|c|c|c|c|c|}
\hline Indicators & Jan 08 & Mar 08 & June 08 & Sept 08 & Dec 08 \\
\hline Projects approved & - & 2100 & 3256 & 2951 & 1966 \\
\hline $\begin{array}{l}\text { Capital investment size } \\
\text { (in million Birr) }\end{array}$ & - & $45,026.9$ & 61333.2 & $31,497.3$ & $28,510.3$ \\
\hline $\begin{array}{l}\text { Potential Employment } \\
\text { Creation (Permanent and } \\
\text { Temporary) }\end{array}$ & - & 362912 & 672489 & 391994 & 240960 \\
\hline
\end{tabular}

Source (National Bank of Ethiopia, 2009)

\section{Conclusions and recommendations}

Ethiopia was unable to reap the benefits of international price fall because of the serious foreign exchange shortage. Foreign reserve crisis coupled with high inflation rate is now crippling the country. Foreign direct investment is also likely to decline significantly although it is too early to show its overall impact on the economy. On the other hand, because donor countries are in deep recession themselves, the external grant and loan assistance would decline. From the discussion on the effect of the global crisis on Ethiopia, the following policy adjustments need to be implemented to avoid further worsening of the economic condition in the country.

1. Export diversification: Being an underdeveloped economy that heavily depends on agriculture, the structure of Ethiopian export is dominated by agricultural products. The share of primary products in the export sector is significant, and should be diversified to other industrial activities. The diversification will help the country to withstand external shocks that would arise on any particular commodity.

2. Strengthening the Ethiopian commodity exchange (ECX): The government of Ethiopia has to establish a reliable network through which export items are delivered to the international market. Recent developments like the Ethiopian Commodity Exchange (ECX) are positive moves towards achieving a transparent and efficient transaction for the collection and delivery of agricultural products.

3. Strengthening the foreign currency base: Depleted foreign reserves lead to shortage in available funds for imports. Importable items in the Ethiopian case are dominated by machinery and 
medicines, which are essential to the smooth functioning of the overall economy.

4. Encouraging the Ethiopian Diaspora to send remittance through formal banking transactions: The Ethiopian Diaspora living abroad can be considered as important source of foreign currency and income for the country. Therefore, policies have to be formulated towards greater efficiency that encourages the Diaspora to send money through formal bank channels.

5. Strengthening local capacity to minimize dependence on foreign assistance: External shocks have huge impacts on countries that depend heavily on international assistance. Ethiopia, being one of them, needs to minimize its reliance on aid. Self sufficiency in terms of mobilization of domestic resources will help to bring about a self sustained economy. 


\section{References}

Abayomi, A. 2008. The Global Economic Crisis and its Impact in East Africa, Pan-African News Wire. Available at http://www.workers.org/2008/world/east_africa_0807/

African Development Bank. 2009. Impact of the Global Financial and Economic Crisis on Africa. Available at http://www.afdb.org/en

Amdissa, T. 2008. The Impact of the Global Financial Crisis on Developing Countries, Institute of Development Studies, Sussex

Bordo, D. 2000. Are financial crises becoming increasingly more contagion? What is the historical evidence on contagion? Rutgers University and NBER. World Bank, USA.

Banerjee, A.1992. A simple model of herd behaviors. Journal of Economics: 107:787-818.

CRS, Report for Congress, 2008. The U.S. Financial Crisis: The Global Dimension with Implications for U.S. Policy. Report for Congress USA. Available at: www.fas.org/sgp/crs/misc/RL34742

Desta A. 2008. The Impact of United States' Financial Meltdown on Ethiopia's Economy: An Observation, Dominican University, California, USA.

Dirk Willem te Velde, 2008 The global financial crisis and developing countries: Which countries are at risk and what can be done?, Overseas Development Institute, UK.

Eichengreen, B., 1992, Financial Crises and What to do about them, New York: Oxford University Press.

Ethiopian Customs Authority, 2008. Export by Destination by Major Commodity for October 2008. Addis Ababa. Ethiopia.

Ethiopian Revenues and Customs Authority, 2009. Values of Major Export Items, Addis Ababa, Ethiopia 
Graham, C.2009. Gross National Happiness and the Economy: Available at; http://www.brookings.edu/opinions/2008/1024_happiness_gr aham.aspx.

IMF, 2009. Impact of the Global Financial Crises on SSA. IMF, New York.USA.

Kindleberger, C. 1986. Manias, Panic and Crashes: A History of Financial Crises. New York: John Wiley.

Krugman, P., 1979. A model of balance of Payment Crisis. Journal of Money, Credit and Banking. 11:311-325.

Minshkin, S. 2000. Asymmetric information and financial crises: A historical perspective, USA: University of Chicago Press.

Minsky,1996. The financial instability hypothesis: A clarification. Handbook of radical political economy, Available at: http://www.levy.org/pubs/wp74.pdf

Mohammed N., 2008. Global Financial Crisis: An African Perspective, Research Division, Strategic Planning and Research Department, African Development Bank.

National Bank of Ethiopia, 2009. The Monthly Macroeconomic Indicators for the Month of January, Addis Ababa, Ethiopia.

National Bank of Ethiopia, 2009. The Monthly Macroeconomic Indicators Quarter I volume 24, Addis Ababa, Ethiopia

National Bank of Ethiopia, 2009. The External Sector Performance for Quarter I volume 24, Addis Ababa, Ethiopia

Reporter Newspaper, (November 2008), Status of Balance of Payment during Third Quarter, Addis Ababa, Available at: http://en.ethiopianreporter.com/content/view/221/1/

World Bank. 2009. Global Development Finance, Charting a Global Recovery, Washington DC .Available at www.worldbank.org 
ANNEXURE -1: Balance of Payments

\begin{tabular}{|c|c|c|c|c|c|c|c|}
\hline \multirow{3}{*}{$\begin{array}{l}\text { Ethiopian Fiscal Year } \\
\text { Particulars } \\
\end{array}$} & \multicolumn{3}{|c|}{ 2007/08 (millions of USD) } & \multicolumn{2}{|c|}{$\begin{array}{c}2008 / 09 \text { (millions } \\
\text { of USD) }\end{array}$} & \multicolumn{2}{|c|}{ Percentage Change } \\
\hline & QI & QII & QIV & QI & QII & & \\
\hline & $\mathbf{Z}$ & A & B & C & D & $\begin{array}{l}E=D- \\
C * 100 / C\end{array}$ & $\begin{array}{l}F=D- \\
A * 100 / A\end{array}$ \\
\hline Trade Balance & -1142.7 & -1312.6 & -1592.4 & -1921.7 & -1766.9 & -8.1 & 34.6 \\
\hline Exports & 265.9 & 267.7 & 457.9 & 351.1 & 270.9 & -22.8 & 1.2 \\
\hline Imports & 1408.6 & 1580.3 & 2050.2 & 2272.8 & 2037.9 & -10.3 & 29.0 \\
\hline Net Services & 20.3 & 70.7 & 9.6 & 149.6 & 169.0 & 13.0 & 139.1 \\
\hline Travel & 5.1 & 34.6 & 67.3 & 62.0 & 46.6 & -24.8 & 34.8 \\
\hline Transportation & 62.7 & 42.2 & 2.4 & 70.1 & 83.4 & 19.0 & 97.7 \\
\hline Government (n.i.e.) & 37.2 & 29.2 & 47.6 & 24.8 & 54.2 & 118.7 & 85.7 \\
\hline Investment income & 10.9 & 11.2 & 4.2 & 3.2 & -5.4 & -268.8 & -148.2 \\
\hline Interest & 14.6 & 16.4 & 7.1 & 7.3 & -1.5 & -120.4 & -109.1 \\
\hline Cash (net) & 14.7 & 16.4 & 7.1 & 7.3 & -1.5 & -120.4 & -109.1 \\
\hline Arrears & 0.0 & 0.0 & 0.0 & 0.0 & 0.0 & - & - \\
\hline Dividend & -3.7 & -5.2 & -2.9 & -4.1 & -3.9 & -4.5 & -24.7 \\
\hline Other Services & -97.6 & -46.5 & -111.9 & -10.5 & -9.8 & -6.2 & -78.8 \\
\hline Private Transfers & 596.4 & 578.3 & 654.2 & 688.2 & 798.6 & 16.0 & 38.1 \\
\hline $\begin{array}{l}\text { Current Account } \\
\text { Balance } \\
\text { (excl.public transfers) }\end{array}$ & -526.0 & -663.5 & -928.6 & -1083.9 & -799.3 & -26.3 & 20.5 \\
\hline Public Transfers* & 138.6 & 358.5 & 483.7 & 281.3 & 513.2 & 82.5 & 43.2 \\
\hline $\begin{array}{l}\text { Current Account } \\
\text { Balance } \\
\text { (incl.public transfers) }\end{array}$ & -387.4 & -305.0 & -444.9 & -802.6 & -286.0 & -64.4 & -6.2 \\
\hline Non-monetary Capital & 172.1 & 331.6 & 357.9 & 372.6 & 416.3 & 11.7 & 25.5 \\
\hline Long-term (net) & 72.5 & 100.7 & 98.4 & 107.6 & 179.7 & 67.1 & 78.4 \\
\hline Disbursements & 78.8 & 115.9 & 109.8 & 114.5 & 188.8 & 64.9 & 62.9 \\
\hline Repayments & 6.3 & 15.2 & 11.4 & 6.9 & 9.1 & 31.1 & -40.1 \\
\hline Cash & 6.3 & 15.2 & 11.4 & 6.9 & 9.1 & 31.1 & -40.1 \\
\hline Arrears & 0.0 & 0.0 & 0.0 & 0.0 & 0.0 & - & - \\
\hline Direct Investment (net) & 162.7 & 192.1 & 282.9 & 264.9 & 226.8 & -14.4 & 18.1 \\
\hline Short-term (net) & -63.2 & 38.8 & -23.4 & 0.1 & 9.8 & 6864.3 & -74.8 \\
\hline $\begin{array}{lll}\text { Net } & \text { Errors } & \text { \& } \\
\text { Omissions } & & \\
\end{array}$ & 428.8 & -167.1 & -68.6 & 287.8 & -174.1 & -160.5 & 4.2 \\
\hline Overall Balance & 207.5 & -140.5 & -155.6 & -142.2 & -43.9 & -69.1 & -68.8 \\
\hline Financing & -207.5 & 140.5 & 155.6 & 142.2 & 43.9 & -69.1 & -68.8 \\
\hline Reserves (-:increase) & -207.5 & 140.5 & 155.6 & 142.2 & 43.9 & -69.1 & -68.8 \\
\hline NBE net foreign asset & -282.3 & 50.7 & 146.1 & 104.8 & -103.0 & -198.3 & -303.1 \\
\hline CBs net foreign asset & 74.7 & 89.8 & 9.5 & 37.5 & 146.9 & 292.0 & 63.6 \\
\hline
\end{tabular}


